\title{
Growth and Reproduction of Annual Sowthistle (Sonchus asper L.) in Response to Environmental Light
}

\author{
Zahra Hosseini Cici $\mathbf{S}^{1-3^{*}}$, Brian Sindel ${ }^{4}$, Steve Adkins ${ }^{2}$ and Jim Hanan ${ }^{2}$ \\ ${ }^{1}$ Payame Noor University, Alborz, Tehran, Iran \\ ${ }^{2}$ CRC for Australian Weed Management, Advanced Modelling and Simulation School, University of Queensland, St Lucia, Brisbane, Australia \\ ${ }^{3}$ School of Plant Agriculture, Shiraz University, Iran \\ ${ }^{4}$ University of New England, Armidale, Australia
}

"Corresponding author: Zahra-Hosseini Cici S, Payame Noor University, \#32, Tohid Square, Karaj, Alborz, Iran, Tel: 026-32283001; Fax: 026-32283000; E-mail: z_h_cici@yahoo.com

Rec date: May 28, 2014, Acc date: Dec 12, 2014, Pub date: Dec 14, 2014

Copyright: (C) $2014 \mathrm{Cici}$ SZH, et al. This is an open-access article distributed under the terms of the Creative Commons Attribution License, which permits unrestricted use, distribution, and reproduction in any medium, provided the original author and source are credited.

\begin{abstract}
Sowthistle (Sonchus asper L.) is believed to be a highly resource demanding species that spreads mainly by seeds. In this study, the effect of light availability on plant size and seed production was investigated. Sowthistle plants showed high phenotypic plasticity in their height, number of leaves, leaf length and number of branches per plant in relation to light availability. Seed mass production per plant ranged from $>3.5 \mathrm{~g}$ in the control to less than 0.2 $\mathrm{g}$ in the $50 \%$ light availability treatment. It was concluded that changing the canopy architecture of crops can suppress growth and seed production in this plant. The results of this research can be used to develop models in crop-weed competition.
\end{abstract}

Keywords: Neutral shade; Seed mass; Annual weed

\section{Introduction}

Annual sowthistle (Sonchus asper L.) is a broad leaf weed from the Asteraceae. It is a common weed among many crops [1]. The ability to germinate at any time of the year, compete well for resources and interfere with crop harvest are the most important features of this weed. One of the resources that has a critical effect on plant growth and development is light availability [2] which is measured by both light quantity and quality [3]. Light is especially important in cropweed competition studies where enough water and nutrients are provided $[4,5]$.

Plants with more access to light will be better able to forage for nutrients than the plants with less access to light [6]. In sustainable agriculture, manipulating the amount of light availability is one of the methods for controlling weeds [7]. It can be achieved through the selection of the appropriate crop cultivars, seeding time, and crop density.

Under the crop canopy both light intensity and red:far red ratios (R:FR ratios) decrease, resulting in decrease in the number of branches and seeds of the weeds. This consequently leads to the reduction of the weeds' seed banks in the long term [8]. For example, McLachlan et al. [4] showed that the amount of light availability changes the leaf initiation rate, the leaf expansion rate, and the final height of redroot pigweed (Amaranthus retroflexus L.). Velvetleaf (Abutilon theophrasti Medicus.) plant height, leaf number, number of branches, dry weight and seed dormancy were also decreased by decreasing the light availability [9]. Reduced light levels also decreased the leaf initiation rate, the area of rosette leaves and the leaf expansion rate of Arabidopsis thaliana L. [10]. In other words, plants needed more time to reach their maximum size.
Despite the widespread importance of annual sowthistle, there is little information available on its requirements for resources such as light, water and nutrients, especially between seedling establishment and seed setting. Since sowthistle is a rosette weed, it was hypothized that manipulating the light availability could be a promising way for suppressing its growth and development. Thus, the aim of this study was to quantify the effects of light availability on sowthistle growth and reproduction capacity.

\section{Materials and Methods}

\section{Plant material}

Sowthistle is a rosette plant that its leaves show phenological variations depending on their positions on the stem. Sowthistle has two different forms of leaf. Rosette leaves close tocauline leaves grow on the upper part of the stem. The length of the stem internodes associated with cauline leaves increases dramatically after the appearance of the first flower buds. Plants can grow to $1.0 \mathrm{~m}$ or more in height [1].

Seeds of sowthistle were collected from plants growing in the Mallard roadside, near Karaj, Alborz, Iran, during several months and kept in a dry and cool place until used in the experiment. The experiment was conducted in a glasshouse during 2011. The average temperature was $26 \pm 3$ and $16 \pm 2 \mathrm{C}$ for day and night time, respectively. Seeds were sown directly in the pots with the size of 20 $\mathrm{cm}$ in diameter and $17 \mathrm{~cm}$ in height. Light textured soil with neutral $\mathrm{pH}$ was used. The soil was watered to the field capacity with tap water and no fertilizers were used. 
Page 2 of 5

\section{Shade treatment}

The treatment period began after the appearance of the first true leaf of the sowthistle seedlings. The experiment consisted of a full-sun treatment (control) and two neutral shade treatments. Plants were randomly assigned to positions on five glasshouse benches, and arranged with sufficient distance among individuals to prevent competition for light. In the neutral shade experiment, plants were placed under vertically adjustable frames covered with black neutraldensity shade cloth (Hummert International, Earth City, MO USA) that reduced photosynethetically active radiationPAR) by c. 70 and $50 \%$ (Red:Far Red=1.03). Pots were regularly rotated (every week) to minimize the variation in their growth.

\section{Data collection}

Leaf number and the time of bolting in sowthistle plants were noted daily. Plant development expressed in terms of phyllochron [11], which is the period of time or the number of degree-days in thermal time between the appearance of one leaf and the appearance of the next. The average phyllochron for sowthistle was obtained by totalling the thermal time taken from the appearance of the first true leaf to the bolting stage and dividing it by the number of leaves produced.

The height of the sowthistle plants was measured (after bolting) every 10 days using a ruler. At the time of harvest, leaves were scanned in a leaf area meter (LI-3100; Li-Cor, Lincoln, NE, USA). The number of capitula and lateral branches were counted on each plant. Five capitula from each sowthistle plant were randomly chosen and their seeds counted. As other seed heads matured they were collected in separate packets and later weighed. Also, the internode lengths in each fully grown sowthistle plant were measured. Finally, 90 days after starting the experiment, the above ground parts of the sowthistle plants were harvested, dried at $70^{\circ} \mathrm{C}$ for 72 hours and then weighed.

\section{Statistical Analysis}

The data on leaf appearance rate and height over thermal time (growing degree-days, GDD), as affected by the different light availability regimes, were analysed using a general linear model. The number of branches, number of capitula, and the amount of biomass were tested with a one-way ANOVA using Minitab 14.0 [12]. Differences between averages were tested by a LSD test for a significance level of $\mathrm{P}<0.05$.

\section{Results}

Sowthistle plants grown under the two lower light availability (50 and $70 \%$ light availability $)$ had significantly $(\mathrm{P}<0.05)$ slower development times (Figure 1 and Table 1) than those grown in full sun light ( $100 \%$ light availability). However, the total number of leaves on the main stem of sowthistle plant at the end of experiment was not affected by the amount of light availability (Figure 1). They all produced $23 \pm 2$ leaves on the main stem. Sowthistle plants grown under 50,70, and $100 \%$ light availability needed about 1090, 940, and 640 GDDs respectively to bolt (Table 1). Phyllochron (Table 1 and Figure 2) was negatively correlated with the amount of light available for growth.

The final leaf area produced in the different treatments was not significantly different (Table 1). The height of sowthistle plants over time was significantly affected by light availability $(\mathrm{P}<0.05$, Figure 3$)$. The final length of internodes in basal nodes of the plants grown under the $50 \%$ light availability regimes was slightly longer than those grown under full light (Figure 4).

\begin{tabular}{|c|c|c|c|c|}
\hline \multirow[t]{2}{*}{ Measured parameters } & \multicolumn{3}{|c|}{ Light availability } & \multirow[b]{2}{*}{$\begin{array}{l}\text { P- } \\
\text { value }\end{array}$} \\
\hline & $50 \%$ & $70 \%$ & $100 \%$ & \\
\hline $\begin{array}{l}\text { Phyllochron (growing degree } \\
\text { days) }\end{array}$ & $48.4 \pm 1$ & $41.4 \pm 0.4$ & $\begin{array}{ll}28.4 & \pm \\
0.5 & \end{array}$ & $<0.05$ \\
\hline Bolting (growing degree days) & $\begin{array}{l}1,090 \pm \\
10\end{array}$ & $940 \pm 5$ & $640 \pm 24$ & $<0.05$ \\
\hline Total leaf area $\left(\mathrm{cm}^{2}\right.$ plant $\left.^{-1}\right)$ & $\begin{array}{l}1437 \quad \pm \\
66\end{array}$ & $\begin{array}{l}1,434 \quad \pm \\
26\end{array}$ & $\begin{array}{l}1,425 \\
21\end{array}$ & $>0.05^{\text {ns }}$ \\
\hline $\begin{array}{l}\text { Total canopy plant biomass ( } \mathrm{g} \\
\text { plant }^{-1} \text { ) }\end{array}$ & $\begin{array}{l}9.52 \quad \pm \\
0.7\end{array}$ & $\begin{array}{l}15.2 \pm \\
1.56\end{array}$ & $\begin{array}{ll}31.6 \quad \pm \\
1.8\end{array}$ & $<0.05$ \\
\hline
\end{tabular}

Table 1: Parameter means and standard errors $( \pm \mathrm{SE})$ recorded from sowthistle plants growing under different levels of light availability (\%).

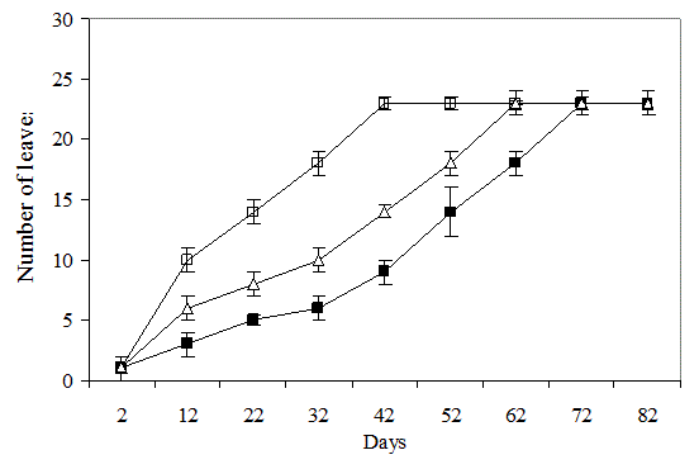

Figure 1: Effect of light availability on leaf appearance on the main stem in sowthistle plants over time; Points and interval bars represent the means and standard errors $( \pm$ SE); $100 \%$ light availability $(\square) ; 70 \%$ light availability $(\Delta)$; $50 \%$ light availability (ロ).

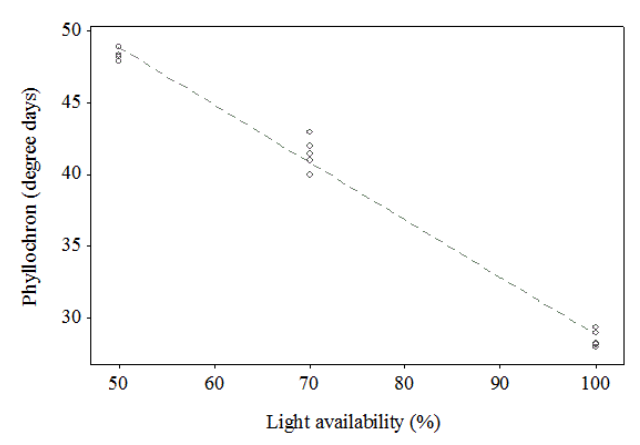

Figure 2: A linear regression between the light availability $(\mathrm{x})$ and the phyllochron of sowthistle plants $(y)$; symbols represent data taken from the experiments and line describes the linear regression, $\mathrm{y}=66-0.38 \mathrm{x}, \mathrm{r}^{2}=0.99$. 
Citation: Cici SZH, Sindel B, Adkins S, Hanan J (2014) Growth and Reproduction of Annual Sowthistle (Sonchus asper L.) in Response to

No noticeable differences were found in the lengths of internodes above node 11 (cauline nodes) in sowthistle plants grown under the different treatments (Figure 4). Sowthistle plant canopy biomass was decreased by 69 and $51 \%$ when the light availability used for growth was 50 and $70 \%$, respectively (Table 1 ).

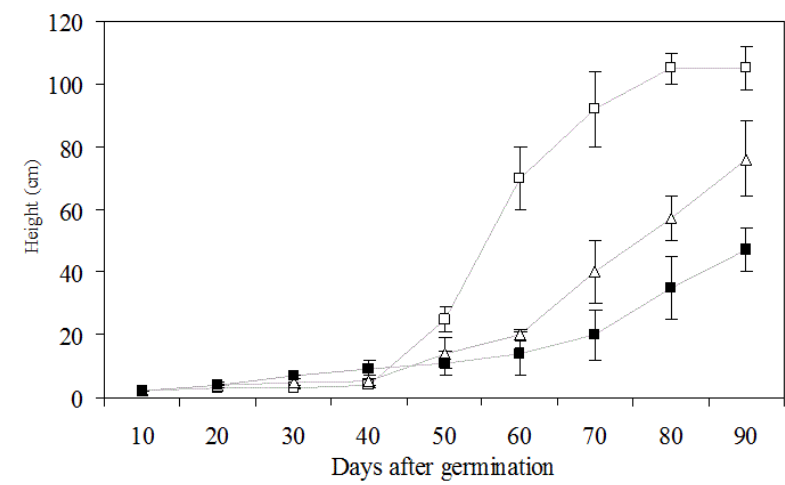

Figure 3: Effect of light availability on height $(\mathrm{cm})$ of sowthistle over time; symbols showing the mean of height over time; vertical bars are standard errors $( \pm \mathrm{SE})$; lines depict the trend of growth; $100 \%$ light availability $(\square) ; 70 \%$ light availability $(\Delta)$; $50 \%$ light availability ( $\mathbf{\square})$.

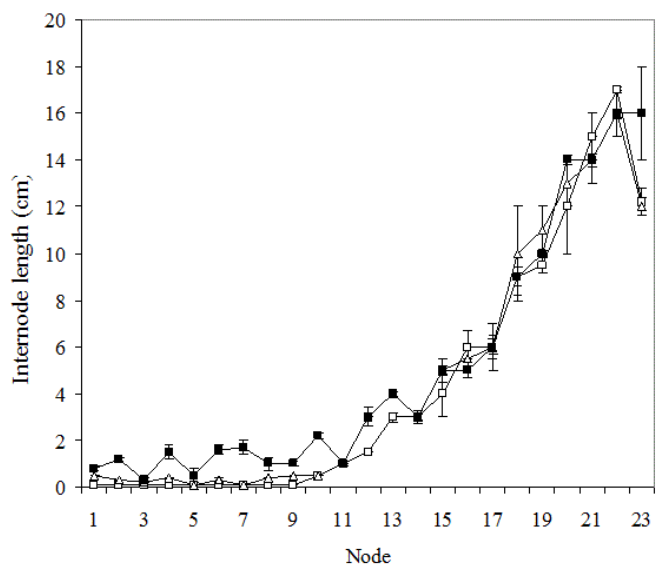

Figure 4: Effect of light availability on internode length $(\mathrm{cm})$ in mature sowthistle plants; Symbols and interval bars represent means and standard errors $( \pm \mathrm{SE})$, respectively. $100 \%$ light availability $(\square) ; 70 \%$ light availability $(\Delta) ; 50 \%$ light availability

The number of branches (Figure 5) and capitula (Figure 6) were also significantly $(\mathrm{P}<0.05)$ reduced by reduced light availability (Table 2 ). Not only the number of capitula but also the number of seeds produced per capitulum was significantly $(\mathrm{P}<0.05)$ decreased by the reduced light availability (Figure 7 ). Consequently the total mass of seeds per plant (Figure 8) was significantly reduced by the reduced light availability as well.

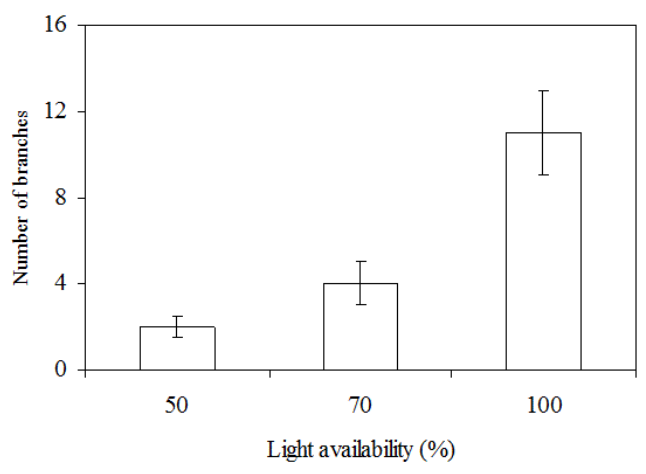

Figure 5: Effect of light availability on the number of branches produced in sowthistle plants, data and interval bars represent the means and standard errors $( \pm S E)$, respectively.

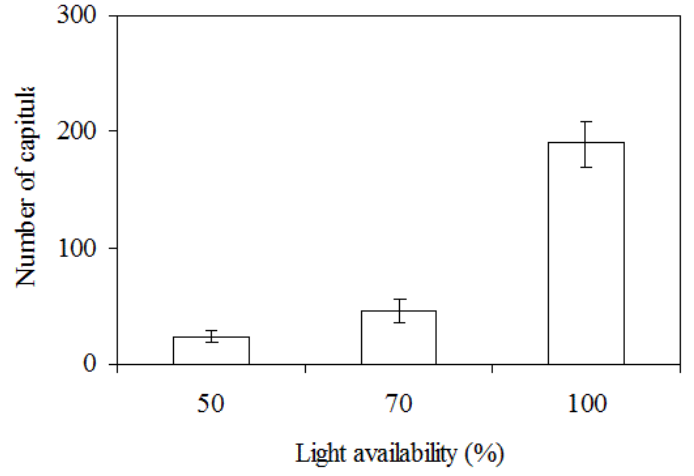

Figure 6: Effect of light availability on the number of capitula produced in individual sowthistle plants, data and interval bars represent the means and standard errors $( \pm \mathrm{SE})$, respectively.

\begin{tabular}{|c|c|c|c|c|c|c|}
\hline $\begin{array}{l}\text { Measured } \\
\text { parameters }\end{array}$ & Model & $\begin{array}{l}\begin{array}{l}\text { Source } \\
\text { variance }\end{array} \text { of } \\
\end{array}$ & ss & d.f & $\mathbf{F}$ & $\mathbf{P}$ \\
\hline Stem Height & GLM & *GDD ? Light & 34,842 & 10 & 350 & $\begin{array}{l}<0.0 \\
5\end{array}$ \\
\hline Branch no plant ${ }^{-1}$ & $\begin{array}{l}\text { ANOV } \\
\text { A }\end{array}$ & Light & 934 & 2 & 539 & $\begin{array}{l}<0.0 \\
5\end{array}$ \\
\hline Capitulum no plant ${ }^{-1}$ & $\begin{array}{l}\text { ANOV } \\
\text { A }\end{array}$ & Light & 208,043 & 2 & 536 & $\begin{array}{l}<0.0 \\
5\end{array}$ \\
\hline Seed no capitulum ${ }^{-1}$ & $\begin{array}{l}\text { ANOV } \\
\text { A }\end{array}$ & Light & 12,636 & 2 & 218 & $\begin{array}{l}<0.0 \\
5\end{array}$ \\
\hline Seed mass plant ${ }^{-1}$ & $\begin{array}{l}\text { ANOV } \\
\text { A }\end{array}$ & Light & 26.9 & 2 & $\begin{array}{l}1,36 \\
1\end{array}$ & $\begin{array}{l}<0.0 \\
5\end{array}$ \\
\hline
\end{tabular}

Table 2: General Linear Model (GLM) and ANOVA of the effects of light availability on sowthistle plant morphogenesis parameters; *GDD: growing degree days. 


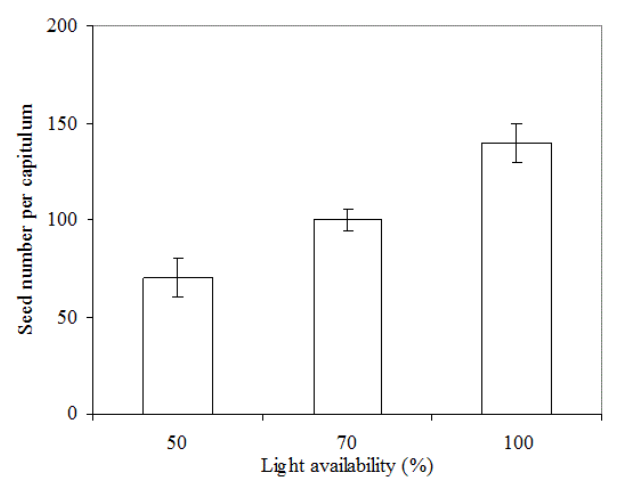

Figure 7: Influence of light availability on the mean seed number per capitulum, data are means of the number of seeds averaged from five randomly selected capitula per plant and interval bars are standard errors $( \pm$ SE).

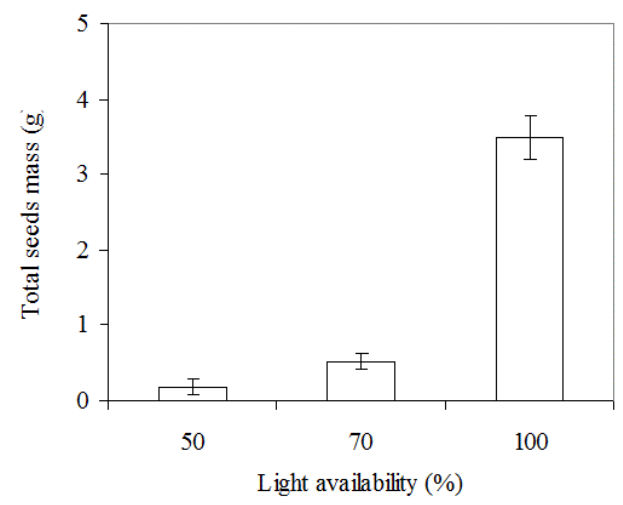

Figure 8: Influence of light availability on the mean of seed mass per sowthistle, data are means of the total seed mass (after 1280 growing degree-days) per plant and the interval bars are standard errors $( \pm \mathrm{SE})$.

\section{Discussion}

Different responses to environmental light have been documented in many plants [13]. In the current experiment, while the final number of leaves on the main stem of the sowthistle were the same in all the treatments, the rate of leaf appearance was slowed by the reduced light environment. Gonzales and Gianoli [14] found similar results in a Convolvulus species. On the basis of reports in the literature [15], in plants under reduced light intensity conditions the time to flowering was delayed while the number of nodes in the main stem did not change. In the case of sowthistle plant, a decrease in light availability delayed the bolting time.

When sowthistle plants were subjected to lower light availabilities (50 and 70\%) they took longer to reach their maximum height. Also, the number of branches, capitula, seed per capitulum and seed mass were all reduced significantly when the level of light was reduced. For example, when the amount of light availability was reduced to 50 and $70 \%$ of the full sun light the number of branches were decreased by about 83 and 58\%, respectively. These findings are consistent with those of Smith and Whitelam [2], who have shown that when light availability is decreased, branching is also decreased. Rajacan et al., [16] reported that the number of branches produced by pigweed plants was more greatly affected by light intensity than by the R:FR ratios.

The biomass of sowthistle plants was significantly reduced as light availability was reduced. A similar response to light has been shown by Gibson et al., [17] in Ammannia coccinnea L. and by Brainard et al., [18] working on Amaranthus powellii L. This is in contrast with the findings of a study by Shrestha and Fidelibus [19] who reported that the light availability over the range included in the experiment did not affect the final biomass production in Solanum nigrum L. plants.

The reduction in sowthistle plant seed production under reduced light availability could be the result of a decrease in the resources allocated to the reproduction of those plants. Similar decreases in the total mass of seeds produced under reduced light availability has been reported for Abutilon theophrasti L. [20], Amaranths powellii L. [18], and Solanum nigrum L. [19]. Bello et al. [9] showed that Abutilon theophrasti L. plants grown under neutral shade could decrease their growth and seed production by as much as $94 \%$ as compared to those grown in full light. Such reductions in seed return have a long term perspective for plant population dynamics and IWM [8]. The results of this experiment can be used in developing models to explore the effect of manipulating light availability in crop production [21].

\section{References}

1. Holm LG, Plucknett DL, Pancho JV, Herberger JP (1977) The world's worst weeds. University Press.

2. Smith H, Whitelam GC (1997) The shade avoidance syndrome: multiple responses mediated by multiple phytochromes. Plant, Cell \& Environment, 20: 840-844.

3. Franklin KA, Quail PH (2010) Phytochrome functions in Arabidopsis development. J Exp Bot 61: 11-24.

4. McLachlan SM, Tollenaar M, Swanton CJ, Weise SF (1993) Effect of corn-induced shading on dry matter accumulation, distribution, and architecture of redroot pigweed (Amaranthus retroflexus). Weed Science 41: 568-573.

5. Cici SZ, Adkins S, Hanan J (2008) A canopy architectural model to study the competitive ability of chickpea with sowthistle. Ann Bot 101: 1311-1318.

6. Keddy PA (2001) Competition. Kluwer Academic Publishers, Dordrecht, The Netherlands.

7. Nazarko OM, Van Acker RC, Entz MH (2005) Strategies and tactics for herbicide use reduction in field crops in Canada: a review. Canadian journal of plant science 85: 457-479.

8. Buhler DD (2009) 50th Anniversary Invited Article: Challenges and opportunities for integrated weed management.

9. Bello IA, Owen MD, Hatterman-Valenti HM (1995) Effect of shade on velvetleaf (Abutilon theophrasti) growth, seed production, and dormancy. Weed Technology 9: 452-455.

10. Cookson SJ, Granier C (2006) A dynamic analysis of the shade-induced plasticity in Arabidopsis thaliana rosette leaf development reveals new components of the shade-adaptative response. Ann Bot 97: 443-452.

11. Rickman RW, Klepper BL (1995) The phyllochron: where do we go in the future?. Crop Science 35: 44-49.

12. Carver RH (2004) Doing data analysis with Minitab 14. Thomson, Victoria.

13. Baythavong BS, Stanton ML (2010) Characterizing selection on phenotypic plasticity in response to natural environmental heterogeneity. Evolution 64: 2904-2920. 
Citation: Cici SZH, Sindel B, Adkins S, Hanan J (2014) Growth and Reproduction of Annual Sowthistle (Sonchus asper L.) in Response to Environmental Light. Agrotechnol 4: 134. doi:10.4172/2168-9881.1000134

Page 5 of 5

14. Gonzalez AV, Gianoli E (2004) Morphological plasticity in response to shading in three Convolvulus species of different ecological breadth. Acta Oeco-Inter J Ecol 26: 185-190.

15. Stinchcombe JR, Izem R, Heschel MS, McGoey BV, Schmitt J (2010) Across-environment genetic correlations and the frequency of selective environments shape the evolutionary dynamics of growth rate in Impatiens capensis. Evolution 64: 2887-2903.

16. Rajcan I, AghaAlikhani M, Swanton CJ, Tollenaar M (2002) Development of redroot pigweed is influenced by light spectral quality and quantity. Crop science 42: 1930-1936.

17. Gibson KD, Fischer AJ, Foin TC (2001) Shading and the growth and photosynthetic responses of Ammannia coccinnea. Weed research 41: 59-67.
18. Brainard DC, Bellinder RR, DiTommaso A (2005) Effects of canopy shade on the morphology, phenology, and seed characteristics of Powell amaranth (Amaranthus powellii). Weed Science 53:175-186.

19. Shrestha A, Fidelibus M (2005) Grapevine row orientation affects light environment, growth, and development of black nightshade (Solanum nigrum).Weed science 53: 802-812.

20. Steinmaus SJ, Norris RF (2002) Growth analysis and canopy architecture of velvetleaf grown under light conditions representative of irrigated Mediterranean-type agroecosystems. Weed science 50: 42-53.

21. Cici Szh, Adkins S, Hanan J (2009) Modelling the morphogenesis of annual sowthistle, a common weed in crops. Computers and Electronics in Agriculture 69: 40-45. 